\title{
Entrepreneurial Motivation
}

\author{
Scott Shane, Edwin A. Locke, Christopher J. Collins
}

Recent research on entrepreneurship has focused largely on macro-level environmental forces [Aldrich, H. (2000). Organizations evolving. Beverly Hills: Sage] and the characteristics of entrepreneurial opportunities [Christiansen, C. (1997). The innovators dilemma. Cambridge: Harvard Business School Press]. Although researchers adopting this focus have rightly criticized much of the existing empirical research on the role of human motivation in entrepreneurship [Aldrich, H., \& Zimmer, C. (1986). Entrepreneurship through social networks. In D. Sexton \& R. Smilor (Eds.), The art and science of entrepreneurship (pp. 3-23). Cambridge, MA: Ballinger; Adm. Sci. Q. 32 (1987) 570], we believe that the development of entrepreneurship theory requires consideration of the motivations of people making entrepreneurial decisions. To provide a road map for researchers interested in this area, we discuss the major motivations that prior researchers have suggested should influence the entrepreneurial process, as well as suggest some motivations that are less commonly studied in this area. In addition to outlining the major reasons for exploring these motivations, we identify the major weaknesses that have limited the predictive power of previous research on this topic. We offer explicit solutions for future research to adopt to overcome these problems.

\section{Introduction}

It is often said that a person cannot win a game that they do not play. In the context of entrepreneurship, this statement suggests that success depends on people's willingness to become entrepreneurs. Moreover, because the pursuit of entrepreneurial opportunity is an evolutionary process in which people select out at many steps along the way, decisions made after the discovery of opportunities - to positively evaluate opportunities, to pursue resources, and to design the mechanisms of exploitation-also depend on the willingness of people to "play" the game. In this paper, we argue that human motivations influence these decisions, and that variance across people in these motivations will influence who pursues entrepreneurial opportunities, who assembles resources, and how people undertake the entrepreneurial process.

In recent years, entrepreneurship research has focused largely on the environmental characteristics influencing firm-foundings (Aldrich, 2000) and the characteristics of entrepreneurial opportunities (Christiansen, 1997). Although this focus has greatly enhanced our understanding of the entrepreneurial phenomenon, it ignores the role of human agency. Entrepreneurship depends on the decisions that people make about how to undertake that process. We argue that the attributes of people making decisions about the entrepreneurial process influence the decisions that they make. Although previous researchers have rightly criticized much of the existing empirical research on the role of human motivation in entrepreneurship (Aldrich \& Zimmer, 1986; Carroll \& Mosakowski, 1987), we argue that inadequate empirical work does not negate the importance of understanding the role of human motivation in the entrepreneurial process. In fact, even sociologists who have argued strongly against the usefulness of trait-based 
research in entrepreneurship implicitly acknowledge that motivation must matter to this process. Aldrich and Zimmer (1986, p. 3), for example, write, entrepreneurial activity "can be conceptualized as a function of opportunity structures and motivated entrepreneurs with access to resources" (italics added).

We also believe that these criticisms have resulted in insufficient consideration of the role of the human motivation in the entrepreneurial process in recent entrepreneurship research. Consequently, we are left with theories of entrepreneurship that do not consider variation in the motivations of different people. We believe that such an omission is problematic because, as Baumol (1968, p. 66) eloquently argued, the study of entrepreneurship that does not explicitly consider entrepreneurs is like the analysis of Shakespeare in which "the Prince of Denmark has been expunged from the discussion of Hamlet."

In this article, we identify several human motivations that influence the entrepreneurial process. In our arguments, we explicitly assume that all human action is the result of both motivational and cognitive factors, the latter including ability, intelligence, and skills (Locke, 2000a). We also assume that entrepreneurship is not solely the result of human action; external factors also play a role (e.g., the status of the economy, the availability of venture capital, the actions of competitors, and government regulations). However, environmental factors being held constant, we argue that human motivation plays a critical role in the entrepreneurial process. To this end, we suggest ways that researchers could develop more realistic explanations for how human motivation influences the entrepreneurial process than is the norm in the literature to date. We believe that this approach could overcome many of the criticisms of prior research on personcentric explanations for entrepreneurship. Finally, we offer suggestions on how empirical researchers should test these arguments in ways that overcome many of the criticisms of extant research on this topic.

Our article proceeds as follows: In the second section, we define entrepreneurship and present several arguments for why the study of entrepreneurship in general and consideration of the role of human motivation in the process in particular are important. In the third section, we discuss opposing views of how opportunities may affect the relationship between motivation and entrepreneurship. In the fourth section, we summarize the major mechanisms by which previous researchers believe motivation influences entrepreneurship. In the fifth section, we identify what we believe are the major problems with prior research on motivation and entrepreneurship. In the sixth section, we provide some recommendations for researchers conducting empirical research in this area. In the final section, we offer some tentative conclusions about motivation and entrepreneurship.

\section{What is entrepreneurship and why study it from the point of view of human motivation?}

We believe that the study of the entrepreneurial process is important for several reasons. First, entrepreneurship drives innovation and technical change, and therefore generates economic growth (Schumpeter, 1934). Second, as the Austrian economists have explained, entrepreneurial action is the process through which supply and demand are equilibrated (Kirzner, 1997). Third, entrepreneurship is an important process by which 
new knowledge is converted into products and services (Shane \& Venkataraman, 2000). Fourth, entrepreneurship has become an important vocation and we need to understand its role in the development of human and intellectual capital (Zahra \& Dess, 2001).

In this article, we adopt Shane and Venkataraman's (2000, p. 218) definition of entrepreneurship as the process by which "opportunities to create future goods and services are discovered, evaluated, and exploited." As these authors have explained, this definition does not require viewing entrepreneurs as the founders of new organizations. ${ }^{1}$ An options trader can be an entrepreneur, as can a corporate salesman who discovers and pursues opportunities for the creation of new products. ${ }^{2}$ Moreover, this definition shows that entrepreneurship is a creative process. By rearranging resources in a new way, entrepreneurs engage in creative activity. However, the degree of creativity involved in entrepreneurship varies across the types of resource recombination that occurs. For example, the creation of business to undertake space tourism may be more creative than the creation of a new restaurant in a strip mall.

Entrepreneurship involves human agency. The entrepreneurial process occurs because people act to pursue opportunities. People differ in their willingness and abilities to act on these opportunities because they are different from each other. We argue that the variation among people in their willingness and ability to act has important effects on the entrepreneurial process.

Recent research has been relatively accepting of arguments that people vary in their willingness and ability to engage in the entrepreneurial process because of nonmotivational individual differences. Researchers have shown that the willingness of people to pursue entrepreneurial opportunities depends on such things as their opportunity cost (Amit, Meuller, \& Cockburn, 1995), their stocks of financial capital (Evans \& Leighton, 1989), their social ties to investors (Aldrich \& Zimmer, 1986), and their career experience (Carroll \& Mosakowski, 1987; Cooper, Woo, \& Dunkleberg, 1989).

We argue that motivational differences also influence the entrepreneurial process. For example, such things as variation across people in their perceptions of risk and opportunity influence entrepreneurial decisions (Shane \& Venkataraman, 2000). People vary in how they view the risk of expending resources before knowing the distribution of outcomes (Palich \& Bagby, 1995). Similarly, the probability of success at the entrepreneurial process is low, and those people who are willing to proceed despite these odds might be more optimistic or higher in self-efficacy than people deterred by these odds. We consider the incorporation of this individual-level variation in motivation to be important to the entrepreneurial process.

To isolate the effects of entrepreneurial motivation, other factors that could have a causal effect on the process and outcome of entrepreneurship need to be controlled. One category of control variables is the external environment. These would include such things as (1) political factors (e.g., legal restrictions, quality of law enforcement, political stability, and currency stability); (2) market forces (e.g., structure of the industry, technology regime, potential barriers to entry, market size, and population demographics); and (3) resources (e.g., availability of investment capital, labor market including skill availability, transportation infrastructure, and complementary technology). Most researchers either explicitly or implicitly agree that these categories of factors influence the entrepreneurial process and need to be controlled to measure the effect of motivations on the entrepreneurial process. ${ }^{3}$ 
While it is clear why the above factors need to be controlled if we are to fully understand how motivation is related to entrepreneurship, it is less clear how opportunities affect this relationship. Because the first two authors were unable to agree on the concept of opportunities, we present two versions of the relationship between opportunities and motivation. First, we will present the view shared by Shane and Collins, then we will present Locke's view.

\section{Entrepreneurs, opportunities, and the effects of motivation: Shane and Collins' version}

Opportunities are aspects of the environment that represent potentialities for profit making. We follow Shane and Venkataraman (2000, p. 220) to define entrepreneurial opportunities as "situations in which new goods, services, raw materials, and organizing methods can be introduced and sold at greater than the cost of their production." Since potentialities are not yet actual, measuring them objectively and prospectively at the level of an individual entrepreneur poses daunting challenges.

Entrepreneurs can pursue opportunities in any industry at any time. For example, some entrepreneurs build successful new companies by contributing to the founding of a new industry, such as Robert Swanson in biotechnology. Other entrepreneurs build new companies in old and mature industries such as Sam Walton in retailing.

Aggregate statistics show us that the general category of opportunities to which Sam Walton and Bob Swanson responded was not equal. The average value of new businesses created in retail is lower than the average value of new businesses created in biotechnology. Because human motivations are likely widely distributed across industry categories at the aggregate level, statistically significant differences in the mean value of businesses created in different industry categories suggest that the value of opportunities varies across industry. This does not mean that entrepreneurs cannot successfully pursue opportunities in low-opportunity industries. Rather it means that the opportunities in these industries are simply less attractive to the average person.

The value of opportunities also varies within industries. Because the opportunities that entrepreneurs identify and pursue have different economic value, the opportunities themselves influence entrepreneurial behavior. We believe that it is important for behaviorally oriented entrepreneurship researchers to consider and measure the economic value of these opportunities in research about the motivations of entrepreneurs.

For example, in the early 1970s, Butler Lampson and Chuck Thacker, researchers at Xerox Parc, invented the Alto-the first personal computer (PC). However, their design would have cost over US\$10,000 to build. When Steve Jobs and Steve Wozniak came up with the design for the Apple computer, their design cost less than US\$3000 to build. Because the number of people who would pay more than US $\$ 10,000$ for a PC was much smaller than number of people who would pay US\$3000, the financial value of the Jobs and Wozniak opportunity was greater than the value of the Xerox opportunity. One would expect that differences in the estimates of the value of the PC opportunity that resulted from the different solutions influenced the decisions of the different parties about their opportunities. Of course, although it is possible that Jobs and Wozniak possessed more of the relevant motives to pursue entrepreneurial opportunities than did Lampson and 
Thacker, researchers can only estimate the effect of these motives if they account for the differences in the two opportunities.

Although we argue that opportunities influence entrepreneurial behavior, we do not argue that opportunities fully determine the process. Entrepreneurs are people and may make different decisions when confronted with similar opportunities. In addition to being influenced by the opportunity that Steve Jobs pursued at the time of founding, the development of Apple was likely influenced by Steve Jobs' motivations.

Empirically, the objective and subjective parts of opportunity are difficult to separate. The mechanism for actualizing an opportunity often initially exists mainly in the entrepreneur's mind, making the entrepreneur's idea for how to exploit the opportunity a personal interpretation of the opportunity. This idea is basically what we would call vision. Such judgments may be mistaken; entrepreneurs sometimes believe that they have identified valuable opportunities when, in fact, no valuable opportunities actually existed, at least in the form in which they were conceptualized (e.g., Federal Express's abortive attempt at Zap Mail).

Also, entrepreneurs may differ in how they interpret opportunities. For example, the development of the Internet has allowed entrepreneurs to develop new organizing methods, such as "e-tailing," that were never before possible. Although a wide variety of entrepreneurs have responded to the opportunities to develop new organizing methods that the Internet has generated, these entrepreneurs have developed approaches of different value in response to this organizing opportunity. Some entrepreneurs have developed opportunities to compete with established retailers through e-tailing, while others have sought only to design web sites. Even though the way that opportunities are manifested in the entrepreneur's plans for exploitation are personal, the variance in their estimated value likely influences the decisions that people make in the entrepreneurial process and can confound attempts to measure the effects of motivation on this process. This is true even if the value is partially a function of the other decisions that the entrepreneur has made and partially a function of external forces.

\section{Entrepreneurs, opportunities', and the effects of motivation: Locke's version}

Opportunities are aspects of the environment viewed from a certain perspective. We view opportunities as potentialities for profit making. Since potentialities are not yet actual, we would argue that they could not be measured except in the negative sense, that is, in terms of metaphysical limitations or upper limits. For example, there is virtually no potential market for Mercedes cars in countries where the median annual income is US $\$ 1000$. Similarly, the potential profit is higher for a general retailer than a comb manufacturer due to a difference in the scope of the business. Furthermore, one can calculate the average profitability of previous entrants into an already existing market (e.g., house building). But one cannot quantify what an entrepreneur might do that has never been done before.

For example, consider discount retailing. When Wal-Mart entered the discount retail business, the size and dollar value of the existing retail market were known. So this could be considered an "opportunity." But what could not have been known was how much of that market Wal-Mart could actually capture (e.g., $0.01 \%, 5 \%, 30 \%, 50 \%, 75 \%$ ) and how much they could grow the whole market subsequently by attracting buyers who would not 
ordinarily shop for discounts. This would depend, at least in part, on Sam Walton. Thousands of other retailers with the same "opportunity" as Wal-Mart went nowhere or remained small players. Other big players fell on hard times (Sears, K-Mart). At the same time, new competitors sprang up (Target, Costco), which could have been a threat to WalMart. Certainly, Sam Walton took advantage of an opportunity but, in part, he created the opportunity himself through his own entrepreneurial actions.

Consider an even more complex example: the PC market. Before Apple Computer, there was not much of a PC market outside of a few schools and businesses and a few thousand hobbyists using primitive computers. So what was the "opportunity?" There was mainly a potential market-people who might buy a more sophisticated PC if offered. The success of the PC would depend on Steve Jobs' approach, including the quality of the design features, the software, the price, and Apple's ability to market the product. Again, in a certain sense, Jobs created the mass market. There was no way of knowing in advance what the size of the market would be because Jobs was asking people to buy something that did not exist before. Nor could it be known if Apple would dominate the market that they created or, due to strategic errors, they would lose most of it to rivals-as they did.

The most obvious means of controlling for environment and opportunity-insofar as they can be controlled for-are (1) to use a sample of entrepreneurs within the same industry and country (or region); ${ }^{4}$ and (2) to measure aspects of the environment that might vary within industry and region (for an example of both, see Baum et al., 2001). While these controls would eliminate much of the problem, they do not eliminate it completely. This is because realizing an actuality out of potentiality depends not on any mechanical laws of finance but on free will-the capacity of the human mind to discover, through creative thought, solutions that had not existed before. This is what I have elsewhere called vision (Locke, 2000b).

\section{Motivation and entrepreneurship: important motivational concepts from prior quantitative research}

Previous research has explored several motivations and their effects on entrepreneurship. In this section, we discuss several of these concepts. However, we do not provide a complete review of prior empirical research for two reasons. First, the definitions of entrepreneurship used in previous empirical research on motivation and entrepreneurship are inconsistent with our definition, making it impossible to draw direct implications of prior work for research using our definition. ${ }^{5}$ Second, prior research has suffered from significant methodological problems that we discuss below, making prior findings suggestive rather than conclusive, even for research that employs the same definition of entrepreneurship as was used in those studies. Therefore, we discuss previous empirical research only to illustrate the ways in which motivation can influence different aspects of the entrepreneurial process.

\section{Need for achievement}

Within the research domain of personality traits and entrepreneurship, the concept of need for achievement (nAch) has received much attention. McClelland (1961) argued that individuals who are high in nAch are more likely than those who are low in nAch to 
engage in activities or tasks that have a high degree of individual responsibility for outcomes, require individual skill and effort, have a moderate degree of risk, and include clear feedback on performance. Futher, McClelland argued that entrepreneurial roles are characterized as having a greater degree of these task attributes than other careers; thus, it is likely that people high in nAch will be more likely to pursue entrepreneurial jobs than other types of roles.

Johnson (1990) conducted a traditional review of 23 studies, which varied regarding samples, measurement of $n A c h$, and definitions of entrepreneurship. Based on this group of studies, Johnson concluded that there is a relationship between $\mathrm{nAch}$ and entrepreneurial activity-in this case, nAch distinguished firm founders from other members of society. In a similar review of 19 studies, Fineman (1977) concluded that both projective and questionnaire measures of nAch significantly predict firm founding.

Collins, Locke, and Hanges (2000) conducted the first and only meta-analysis of nAch and entrepreneurship studies, examining 63 nAch and entrepreneurship studies. The overall finding of the meta-analysis is that nAch is significantly related to founding a company. The nAch both differentiated between entrepreneurs and others (mean $r=.21$ ) and predicted the performance of the founders' firms (mean $r=.28$ ). Further, they found no significant differences in the predictive validity of three different measures of nAch (TAT, questionnaires, and the Miner Sentence Completion Scale).

Moreover, Collins et al. (2000) found that the relationship between nAch and entrepreneurial activity was moderated by several factors. First, nAch was a more robust predictor of group-level effects (e.g., mean differences between firm founders and another profession, mean differences between high-performing and low-performing founders) than individuallevel effects (e.g., predicting the performance of individuals). Second, they found that while nAch is a strong differentiator between firm founders and nonmanagerial employees (mean $r=.39$ ), it is not a strong differentiator between firm founders and managers (mean $r=.14$ ).

Based on these results, Collins et al. (2000) concluded that nAch is an effective tool for differentiating between firm founders and the general population but less so for differentiating between firm founders and managers. Further, they concluded that nAch might be particularly effective at differentiating between successful and unsuccessful groups of firm founders. Thus, nAch could play a very useful role in explaining entrepreneurial activity.

\section{Risk taking}

Risk-taking propensity is another motivation of interest, which emerged from McClelland's (1961) original research on entrepreneurs. McClelland claimed that individuals with high achievement needs would have moderate propensities to take risk. This claim by McClelland is especially interesting for entrepreneurship research because the entrepreneurial process involves acting in the face of uncertainty. Liles (1974) argued that entrepreneurs often must accept uncertainty with respect to financial well-being, psychic well-being, career security, and family relations. Moreover, several theories of entrepreneurship view the entrepreneur as bearing residual uncertainty (Venkataraman, 1997). 
Atkinson (1957) argued that individuals who have higher achievement motivation should prefer activities of intermediate risk because these types of activities will provide a challenge, yet appear to be attainable. On the other hand, individuals who score high on the motive to avoid failure will avoid intermediate risks. Instead, they will prefer easy and safe under-takings (because there is a high chance of success) or extremely difficult and risky ones (because it will be easy to explain failure without accepting personal blame). Following the lead of Atkinson, risk-taking propensity has been defined in the entrepreneurship literature as the willingness to take moderate risks (Begley, 1995).

Despite these theoretical claims, previous research suggests that firm owners do not differ significantly from managers or even the general population in risk taking (Low \& Macmillan, 1988). For example, Litzinger (1961) failed to find any difference between motel owners and motel managers on risk preference. Kogan and Wallach (1964) found that firm founders clustered around the mean risk-taking score of the general population. In comparisons of firm founders and managers, neither Babb and Babb (1992) nor Palich and Bagby (1995) found significant differences between the two groups in terms of risktaking propensity. However, none of the above studies identified if firm founders were low, moderate, or high risk-takers. Only Brockhaus (1980) tested for the actual level of risk taking, and he found that firm founders did prefer moderate risk but did not differ from managers in this regard.

Only one study found a difference between firm founders and managers in this motivation. In a study of 239 New England business executives, Begley (1995) found that risk-taking propensity was the only trait on which founders and nonfounders differed. As with the studies described above, Begley failed to identify whether the level of entrepreneurial risk taking was low, moderate, or high.

While these empirical findings suggest that risk taking may or may not be an entrepreneurial motivation, self-efficacy may be confounding the findings. Several recent evaluative studies using interviews and expert evaluations (e.g., Corman, Perles, \& Vancini, 1998; Fry, 1993) showed that firm founders objectively have a higher propensity for risk than do members of the general population, but that firm founders do not perceive their actions as risky. Similarly, Sarasvathy, Simon, and Lave (1998) found that when expert firm founders were asked to evaluate the same entrepreneurial simulations as bankers, the firm founders saw opportunities in information that the bankers thought indicated risk. Thus, the measurement of risk-taking propensity may be confounded with high self-efficacy.

\section{Tolerance for ambiguity}

Schere (1982) argued that tolerance for ambiguity is an important trait for entrepreneurs because the challenges and potential for success associated with business start-ups are by nature unpredictable. Budner (1982) defined tolerance for ambiguity as the propensity to view situations without clear outcomes as attractive rather than threatening. Because entrepreneurs continually face more uncertainty in their everyday environment than do managers of established organizations, entrepreneurs who remain in their jobs are likely to score high on tests for this trait than would managers.

There is mixed support for this prediction. Begley and Boyd (1987) found that firm founders scored significantly higher in tolerance for ambiguity than did managers, defined as non-founders working in business. In smaller sample studies, both Schere (1982) and 
Miller and Drodge (1986) found that firm founders were significantly higher in tolerance for ambiguity than were managers. Finally, based on a review of four additional studies, Sexton and Bowman (1986) identified tolerance for ambiguity as a distinguishing psychological characteristic between firm founders and managers.

However, several studies did not match these findings. Babb and Babb (1992) found no significant difference in tolerance for ambiguity between founders and non-founders of rural businesses in Northern Florida. Similarly, Begley (1995) found no significant differences between New England firm founders and managers on their tolerance for ambiguity. This inconsistency in findings and potential methodological problems in the research that provides support for the tolerance of ambiguity proposition suggests that we do not yet know if tolerance of ambiguity is a motivation that affects any part of the entrepreneurial process.

\section{Locus of control}

Another motivational trait that has received attention is locus of control-the belief in the extent to which individuals believe that their actions or personal characteristics affect outcomes. Individuals who have an external locus of control believe that the outcome of an extent is out of their control, whereas individuals with an internal locus of control believe that their personal actions directly affect the outcome of an event (Rotter, 1966). As McClelland (1961) discussed earlier, individuals who are high in nAch prefer situations in which they feel that they have direct control over outcomes or in which they feel that they can directly see how their effort affects outcomes of a given event. This point was extended by Rotter (1966) who argued that individuals with an internal locus of control would be likely to seek entrepreneurial roles because they desire positions in which their actions have a direct impact on results.

The research on locus of control suggests that firm founders differ from the general population in terms of locus of control. Shapero (1977) found that firm founders from Texas and Italy were more "internal" than other groups of professions reported by Rotter (1966). This same pattern holds with female firm founders versus the general female population (Bowen \& Hisrich, 1986) and with Black firm founders versus the general Black population (Durand, 1975).

While locus of control orientation differs between firm founders and the general public, most studies have not found a difference between firm founders and managers on locus of control, a result similar to the situation with studies on nAch. For example, Babb and Babb (1992) found no differences in locus of control between founders and managers in small businesses in Northern Florida. Similarly, Brockhaus (1982) found that managers and owners of new businesses did not differ on locus of control. In a longitudinal study of students, Hull, Bosley, and Udell (1980) found that locus of control did not differentiate between students who went on to work in managerial positions and those who started their own business. Finally, in the studies of New England entrepreneurs, Begley (1995) and Begley and Boyd (1987) found that locus of control did not distinguish between founders and managers. We suspect that one reason for the difference between firm founder and the general population, but not between founders and managers, is the similarity between founding a company and managing. Defining entrepreneurial situations as starting a company rather than working for others might not capture the real differences 
between entrepreneurial and non-entrepreneurial situations. For example, serving as a manager in a rapidly growing high-technology company might demand greater entrepreneurial motivations than starting a corner grocery store.

Self-efficacy

Self-efficacy is the belief in one's ability to muster and implement the necessary personal resources, skills, and competencies to attain a certain level of achievement on a given task (Bandura, 1997). In other words, self-efficacy can be seen as task-specific selfconfidence. Self-efficacy for a specific task has been shown to be a robust predictor of an individual's performance in that task and helps to explain why people of equal ability can perform differently. An individual with high self-efficacy for a given task will exert more effort for a greater length of time, persist through setbacks, set and accept higher goals, and develop better plans and strategies for the task. A person with high self-efficacy will also take negative feedback in a more positive manner and use that feedback to improve their performance. These attributes of self-efficacy may be important to the entrepreneurial process because these situations are often ambiguous ones in which effort, persistence, and planning are important.

One study directly assessed the effect of self-efficacy on some dimension of the entrepreneurial process. Baum (1994) assessed firm founders in the architectural woodworking industry on a number of variables including general traits and motives (e.g., tenacity and positive affectivity), specific skills and competencies (e.g., industry experience and technical skills), situation-specific motivation (e.g., goal setting and self-efficacy), vision, and strategic action (e.g., quality and service emphasis). In a LISREL model, Baum found that self-efficacy (measured as the self-efficacy to grow the company) had a strong positive relationship with realized growth. In fact, it was the single best predictor in the entire array of variables.

\section{Goal setting}

Tracy, Locke, and Renard (1998) conducted a study of the owners of small printing firms. Both concurrent and longitudinal measures of four aspects of performance were obtained: financial performance, growth, and innovation. The quantitative goals the entrepreneurs had for each outcome were significantly related to their corresponding outcomes, both concurrently and longitudinally (nAch in this study was unrelated to performance). Baum, Locke, and Smith (2001) also found that growth goals were significantly related to the subsequent growth of architectural woodworking firms. Although there have been other studies of entrepreneurial goals, to our knowledge, only these two have related quantitative measures of goal difficulty to performance.

\section{Motivation and entrepreneurship: important motivational concepts from prior qualitative research}

The section below is based largely on qualitative observations, including an inductive study based on secondary sources of 70 wealth creators by Locke (2000b). 


\section{Independence}

Independence entails taking the responsibility to use one's own judgment as opposed to blindly following the assertions of others. It also involves taking responsibility for one's own life rather than living off the efforts of others.

Many investigators have observed that the entrepreneurial role necessitates independence. First, the entrepreneur takes responsibility for pursuing an opportunity did not exist before. Second, entrepreneurs are, in the end, responsible for results, whether achieved or not achieved. Further, individuals may pursue entrepreneurial careers because they desire independence. For example, in interviews with U.S. female firm founders, Hisrich (1985) found that one of the prime motivations for starting a business was a desire for independence.

In addition, there is some existing empirical evidence which suggests that entrepreneurs may be higher in independence than other individuals. Hornaday and Aboud (1973) surveyed 60 founders with several personality inventories and showed that these founders were significantly higher than the general population on measures of independence. Similarly, in a study with 63 founders, Aldridge (1997) found that firm founders scored significantly higher than the general population on personality measures of independence.

Drive

There is some relation between the term drive and that of nAch, but we use the term drive somewhat more broadly. We use it basically to refer to the willingness to put forth effort - both the effort of thinking and the effort involved in bringing one's ideas into reality. When entrepreneurs pursue opportunity, they must take action to make it real.

We differentiate the four aspects of drive: ambition, goals, energy and stamina, and persistence. Ambition influences the degree to which entrepreneurs seek to create something great, important, and significant when they pursue opportunities. The nature of the entrepreneurial ambition may include making money or the desire to create something new, from conception to actuality.

Ambition translates into setting high goals for oneself and others (see the earlier Goal setting section). It is well known that high goals lead to better performance results than moderate or low goals (Locke \& Latham, 1990). To achieve high goals requires enormous energy and stamina. When goal-directed energy is sustained over time, it is called persistence or tenacity. Pursuing an opportunity is never easy; failure at some point or in some respect is an inevitable part of the process.

What sustains such effort over long periods? One factor is high self-efficacy or task-specific confidence-a topic that we covered earlier. The second factor is, strangely enough, love.

\section{Egoistic passion}

More precisely, it is a passionate, selfish love of the work. Some commentators like to pretend that businessmen's core motive is to selflessly serve their employees and 
society. We argue, in contrast, that ego is a central motive. The true or rational egoist passionately loves the work; they love the process of building an organization and making it profitable. They are motivated to do what is actually in their own interest-that is, to do everything necessary.

Surprisingly, there have been virtually no quantitative studies of the role of passion in entrepreneurship. One exception is the study by Baum et al. (2001). Although not shown in that report, when Baum entered passion for the work as a separate variable along with 29 other variables from five domains (personality, situational motivation, skills, strategy, and environment), passion had a direct significant effect on firm growth.

\section{Problems with previous research on human motivation and entrepreneurship and suggested solutions to these problems}

Despite the importance of including individual-level factors in a comprehensive explanation for the entrepreneurial process, previous studies of entrepreneurial motivation have often led to disappointing results (Busenitz \& Barney, 1997). However, we believe that researchers should not conclude from this failure that human motivation is irrelevant to the entrepreneurial process. Rather, we suggest that there are specific reasons for the limited results obtained in previous research.

\section{Controls for opportunities}

Previous research has suffered from a lack of control for the variation in the opportunities that different entrepreneurs pursue (Gartner, 1985). To accurately measure the effects of motivation on entrepreneurial decisions, researchers need to control the effects of opportunities (Shane, 2000, 2001). As Venkataraman (1997) argued, a valuable opportunity for an individual is one that generates a level of profit that exceeds the entrepreneur's opportunity cost, a premium for the illiquidity of money, time, and effort expended, and a premium for bearing risk and uncertainty. Because some opportunities will exceed this threshold by a greater amount than will others, the nature of the opportunity will influence entrepreneurial decisions. Researchers need to know the magnitude of the force exerted by the opportunities themselves to accurately estimate the effect of the individual motivations on entrepreneurial decisions. In the absence of such controls, one cannot know if the effects observed represent the effects of individual motivations or are artifacts of unobserved correlation between the opportunities and the people who pursue them (Shane, 2000, 2001). Prior research has generally failed to control the effect of opportunities by examining entrepreneurs pursuing different opportunities without explicitly modeling the value of the different opportunities pursued.

In addition, prior studies have generally compared managers (who may or may not have identified entrepreneurial opportunities) with firm founders (who have). However, human motivations can influence the tendency of people to engage in entrepreneurial activities only if those activities are possible. If people have not discovered entrepreneurial opportunities or have discovered opportunities but cannot act on those discoveries, it is impossible to determine if their individual motivations make them more or less likely than others to act on entrepreneurial opportunities. Therefore, one 
cannot tell from studies that compare managers to firm founders whether certain motivations influence people to make entrepreneurial decisions unless researchers have ensured that the managers have discovered opportunities and have measured the value of those opportunities. Otherwise, researchers might only capture the fact that some managers have all of the right motivations, but no opportunities in which to use them.

We offer four suggestions to researchers interested in examining the effect of motivations on entrepreneurial decisions about how to deal with variation in opportunities. First, researchers could explore settings in which potential entrepreneurs pursue reasonably identical opportunities. For example, every year, many potential entrepreneurs evaluate and pursue opportunities to purchase McDonald's franchises. When a person applies to be a McDonald's franchisee or company-owned outlet manager, one applies only to be part of the system rather than to select a particular outlet. Therefore, the opportunities to which people respond in this setting are identical. By comparing the motivations of a sample of people seek to be McDonald's franchisees with people who seek to be McDonald's company-owned outlet managers, researchers can determine the contributions of particular motivations on the decision to entrepreneur (see Tracy et al., 1998).

Second, as a variety of researchers are beginning to do, scholars could employ experimental designs in which potential entrepreneurs are asked to make a series of entrepreneurial decisions in a controlled simulation. By measuring the motivations of potential entrepreneurs and examining the correlation between the motivations and the decisions made in these simulations, researchers could determine how motivations influence entrepreneurial decisions.

Third, the most obvious means of controlling opportunity are to use a sample of entrepreneurs within the same industry and country (or region), and to measure aspects of the environment that might vary within industry and region (for an example of both, see Baum et al., 2001). We recommend these approaches to limiting other sources of variance than motivations from studies of motivation and entrepreneurship.

Fourth, as some researchers are beginning to do, scholars could employ third parties to code the value of potential opportunities. For example, researchers could explore the propensity of inventors to found companies based on their inventions. Because all inventors are at risk of exploiting their inventions through firm formation, this setting provides a useful context in which to explore the decision to entrepreneur. By partialing out the externally evaluated value of the opportunities, researchers could determine whether motivations influence the decision to entrepreneur, net of the effects of the value of the opportunity.

\section{Entrepreneurship as a process}

Much of the prior research has looked at entrepreneurship as a profession that certain types of people adopt, rather than as a process that occurs over time. This approach is problematic because the appropriate conceptual lens through which to look at entrepreneurship is as a dynamic process. Because entrepreneurship is episodic and much entrepreneurial action is not long lasting (e.g., raising venture capital is a one-time activity for many entrepreneurs), it is unrealistic to model motivation as dividing entrepreneurs and other members of society into two groups. 
In fact, relatively little of the motivation research on entrepreneurship has considered the effects of motivation on specific steps in the entrepreneurial process. Most studies on motivation and entrepreneurship adopt static designs that seek to determine if firm founders are different from each other, managers, or the general population at the moment the two groups are measured. This approach makes two problematic assumptions. First, it assumes that a given motivation influences all steps in the entrepreneurial process equally, and that the effects of a given motivation do not select out some people at earlier stages in the process. Second, it assumes that, at the moment in which the founders are compared to the others, the founders who are still in charge of the organizations that they founded represent the population of people who engage in entrepreneurial activity.

Because entrepreneurship is a process, with tremendous selection at each step, we believe that these assumptions are quite faulty. The motivations that allow progression from opportunity recognition to resource assembly might not lead from financial assembly to first sales. For example, to assemble resources, a person might need to be highly confident. Those people lacking sufficient overconfidence to assemble resources are selected out of the entrepreneurial process. If there is very little variation in overconfidence among the people who have resources and seek to reach first sales, overconfidence will have no effect on achieving first sales.

For these reasons, we believe that it may not be possible to examine the direct effects of a lead entrepreneur's motivations on the financial performance of a new company that the individual founds. The effects of motivation might be captured by the intervening variables in any causal model of the effects of motivation on firm performance. For example, those higher in nAch might be more likely to obtain venture capital financing. However, once venture capital financing is measured, there is no effect of nAch on firm performance.

We offer several specific suggestions for how researchers could better think about how motivations influence the entrepreneurial process. First, researchers could incorporate motivations into a dynamic evolutionary perspective on entrepreneurship by using motivations to distinguish those individuals who select out at different steps in the entrepreneurial process. For example, motivations could separate those individuals who positively evaluate opportunities from those who do not, those who obtain outside funding from those who do not, those who continue to pursue opportunities from those who abandon the effort, or those who pursue rapid rather than slow growth.

The pursuit of opportunity provides a good example. As Aldrich and Zimmer (1986, p. 14) explain, "opportunities are irrelevant unless taken advantage of, and people vary widely in their ability to seize opportunities" (italics added). We agree, but would argue that people also differ widely in their motivation to seize opportunities. It would be interesting to know if certain motivations predispose people to take action in response to the discovery of opportunities. One might argue, for example, that people higher in self-efficacy will be more likely to seek financing to exploit opportunities than will people lower in self-efficacy. Because the process of financing exposes a person's entrepreneurial ideas to the scrutiny of skeptical others, those people willing to expose their ideas to scrutiny might have to be more confident than those who will not.

Second, researchers could theorize more deeply about how motivation might impact entrepreneurial decisions. Rather than falling back on the stock idea that firm 
founders must be fundamentally different types of people from other members of society, we suggest researchers consider how motivations might influence some people to make different decisions from others in the entrepreneurial process. For example, inventors higher in self- efficacy might found firms to exploit their inventions while inventors lower in self-efficacy might license their technology to others. Similarly, entrepreneurs with a greater need for independence might self-finance new firms, whereas those with a lesser need for independence might seek venture capital.

We also suggest that it is not necessarily important for entrepreneurship researchers to show that specific motivations influence the financial performance of new firms. If financial performance of a new firm is conditional on the ability of an entrepreneur to create the firm, and that act of creation depends heavily on human motivation, then human motivation matters to entrepreneurship even if motivation has no direct effect on the performance of the newly founded firm. In fact, we would expect that the more significant a firm that an entrepreneur founds, the less their motivations influence the firm formation process. For example, the more significant the new firm that an entrepreneur builds, the less influence they will have personally on day-to-day operations, and the less that we would expect the financial performance of the firm to be affected by their personal motivations.

\section{Meta-analysis}

The third criticism of previous research is the failure to use meta-analysis. The ability to combine the results of scores or hundreds of individual studies into a single statistic was not always available to researchers. This sometimes led people who conducted narrative reviews to underestimate the effect of the variable being considered; for example, non-significant results in single studies may be due to sampling error rather than invalidity. Although meta- analytic results are not available for all the motivations we discuss, such data, where available, throw new light on some motivations (however, we caution researchers that the other important conditions we describe, such as controlling for the nature of opportunities and minimizing variation in the types of entrepreneurs, would need to be present in these studies before meta-analysis would provide a valuable technique).

\section{Wrong motives}

A fourth criticism of extant research is its tendency to study the wrong motives. Some motives are more relevant to entrepreneurial activity than others. For example, risk-taking propensity as measured by self-perception and tolerance for ambiguity has long been assumed to be an entrepreneurial motive, but the evidence so far is only equivocal. Regarding risk, perhaps the problem has been that people cannot perceive the riskiness of their own actions, or that what is risky to one person is not risky to another. For example, several recent studies using interviews and expert evaluations (e.g., Corman et al., 1988; Fry, 1993) showed that entrepreneurs objectively have a higher propensity for risk than either entrepreneurs or the general population but that entrepreneurs do not perceive their actions as risky. Thus, the effects of risk-taking propensity may be confounded with the high self-efficacy of entrepreneurs. 
We suggest that researchers better define the motives that they think are important and focus on more precise measures of them. One way to do that would be for researchers to go back to the underlying psychological literature and examine how researchers have dealt with the nuances of theorizing about and measuring the same motives in other settings. If psychologists have figured a way around the problems of using self-perceptions in the measurement of risky behavior, like drug usage, those same techniques can be brought to bear on the measurement of risky behavior in entrepreneurial settings.

We believe that another important step for research on motivation and entrepreneurship would be for researchers to develop more complete models of the entrepreneurial process before examining the effects of particular motives on particular activities. A fuller under- standing of the role of motivations in the overall process would require consideration of factors other than motives. We suggest that researchers develop explanations that include the variety of such influences.

\section{Indirect effects}

A fifth criticism has been the failure to look for indirect effects of motivational traits. Most, though not all, researchers have assumed that traits and motives have direct effects on outcomes and this may be true to some extent. However, an increasing body of literature is revealing that traits affect action indirectly through other mechanisms. For example, in the general realm of work, conscientiousness is a reliable predictor of performance, but there is considerable evidence that the effects of conscientiousness on work performance are mediated by situation-specific factors such as goal setting and goal commitment (Locke, in press). Similarly, Bandura (1997) has argued that locus of control is not a strong, direct predictor of performance in a task; and studies have shown that the effects of self-efficacy mediate the effects of locus of control when selfefficacy is added to the equation (Bandura, 1997). Therefore, locus of control effects reported in the entrepreneurship literature might be proxying unobserved self-efficacy.

One recent study to have taken the approach of considering indirect effects of motivation in the setting of entrepreneurial action is that of Baum et al. (2001), who studied the growth of small companies in the architectural woodworking industry. They included variables from five separate domains: traits and motives (which comprised passion for the work, tenacity, and drive), skills and abilities, situation-specific motivation (e.g., goals, self-efficacy), business strategies, and environmental factors. They combined the measures within each domain into single indexes and related these indexes to each other and to venture growth. All the domains played a role in venture growth but the effects of motives were all indirect. Motives worked through skills, situation-specific motivation, and strategies to affect growth. Given the indirect effects observed in this study, we suggest that researchers consider such indirect patterns in their explanations for the effect of motivation on entrepreneurial action. 


\section{Definitions}

A sixth criticism has stemmed from a lack of consistent definitions of entrepreneurship. In general, the definition of what constitutes entrepreneurial activity varies significantly across studies. For example, McClelland (1965) viewed managerial positions of certain types such as sales as one that demanded entrepreneurial skills, whereas much of the recent work in the applied field of management has sought to compare entrepreneurs to managers. Therefore, it is unclear if the samples from these different studies are comparable, or even represent entrepreneurship in a meaningful way. This point, of course, brings us back to the importance of a common definition of entrepreneurship. As we indicated earlier, we advocate the definition proposed by Shane and Venkataraman (2000). Whether researchers adopt this particular definition, however, is less important than the existence of a common definition. Without a common definition, it will not be possible to accumulate findings that are comparable from study to study.

\section{How motivations influence entrepreneurship}

In this section, we suggest how human motivations might influence the entrepreneurial process. We offer this example to help future researchers design empirical tests of the role of motivation in entrepreneurship. Our example is shown graphically in Fig. 1.

We begin with the set of human motivations that psychologists have shown to influence many aspects of human behavior. These include the motivations that we described earlier in the study, in particular, nAch, locus of control, desire for independence, passion, and drive. We propose that entrepreneurship is a process that begins with the recognition of an entrepreneurial opportunity and is followed by the development of an idea for how to pursue that opportunity, the evaluation of the feasibility of the opportunity, the development of the product or service that will be provided to customers, assembly of human and financial resources, organizational design, and the pursuit of customers.

We suggest that some or all of the motivations influence the transition of individuals from one stage of the entrepreneurial process to another. In some cases, all of the motivations might matter. In other cases, only some of the motivations might matter. The relative magnitudes of how much each motivation matters will likely vary, depending on the part of the process under investigation. In fact, it is quite plausible that motivations that influence one part of the process have all of their effects at that stage in the process and have no effects on later stages in the process.

In this example, motivations are not the only things that influence these transitions. Cognitive factors, including knowledge, skills, and abilities (KSAs), certainly matter. All action is the result of the combination or integration of motivation and cognition (Locke, 2000a). First, the entrepreneurs need to have some knowledge, especially of the industry and of any relevant technology that is critical to success. They can hire people with certain specialized skills that they lack, but they must possess enough expertise to know that they

are doing the right thing. Second, the entrepreneur must have skills. The necessary skills will depend on the circumstances, but they may include such factors as selling and bargaining, leadership, planning, decision making, problem solving, team building, 
communication, and conflict management. Third, the entrepreneur needs to have the requisite abilities, including intelligence. Possessing the necessary KSAs enables the entrepreneurs to develop a viable vision, including a strategy for the organization and to carry it out successfully. Motivation helps the entrepreneur to acquire such KSAs in the first place and provide the impetus and energy to implement the needed actions. The human capital literature in entrepreneurship (e.g., Bates, 1990; Schoonhoven, Eisenhardt, \& Lyman, 1990) has begun to show the effect of certain types of knowledge and skills on the start-up and resource assembly parts of this process.

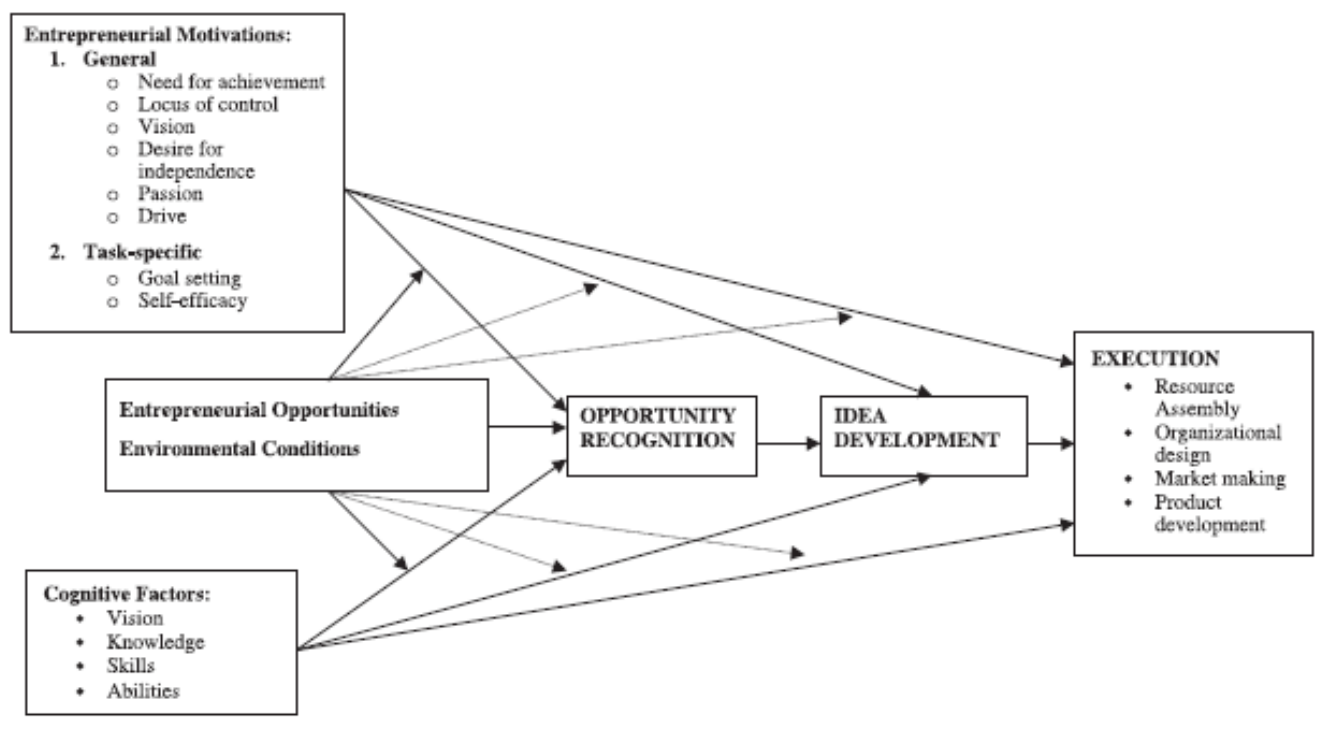

Fig. 1. Model of entrepreneurial motivation and the entrepreneurship process.

The opportunities themselves certainly matter. Prior research has shown that such things as the possession of a patented technology make individuals more likely to engage in the entrepreneurial process (Shane, 2001). One would expect that identification of a large market or a high margin product would do the same.

Furthermore, environmental conditions matter. First, opportunities may interact in interesting ways with the attributes of people. Second, as much of the macro-level research has shown, the willingness to engage in entrepreneurial activities depends on such things as the legal system of the country in which the entrepreneur operates, the age of the industry, the availability of capital in the economy (and to the industry in particular), the condition of capital markets, and the state of the overall economy. We believe that these factors are important, but that it might also be interesting to know whether motivations of particular people lead to different types of entrepreneurial action under different environmental conditions.

Motivations might be more or less stronger than these other factors in the degree that they influence particular transition points. In addition, there might be important and interesting interaction effects between motivations and opportunities, KSAs, and 
environmental factors. The relative importance of different categories of factors, their independent and combined effects, and their relative importance at different stages of the entrepreneurial process are clearly important theoretical and empirical questions that remain largely unexplored. We hope that researchers will begin to explore them because they appear to us to be central issues in the field of entrepreneurship.

\section{Conclusions}

Recent research on entrepreneurship has focused largely on macro-level environmental forces (Aldrich, 2000) and the characteristics of entrepreneurial opportunities (Christiansen, 1997). Although this focus has greatly enhanced our understanding of entrepreneurial activity, it ignores the role of human agency. Entrepreneurial activity depends on the decisions that people make, suggesting that the attributes of the decision makers should influence the entrepreneurial process. Although researchers have rightly criticized much of the existing empirical research on the role of human motivation in entrepreneurship (Aldrich \& Zimmer, 1986; Carroll \& Mosakowski, 1987), we believe that the development of entrepreneurship theory requires consideration of the motivations of people making entrepreneurial decisions.

To provide a road map for this process, we have reviewed the major motivations that prior researchers have suggested should influence the entrepreneurial process, as well as suggested some motivations that are less commonly studied in this area. In addition to outlining the major reasons for exploring these motivations, we have identified the major weaknesses that have limited the predictive power of previous research on this topic. We have pointed out the problems that prior research has faced. Results have been limited, we believe, because prior research has failed to adequately control for entrepreneurial opportunities, has adopted a static perspective on entrepreneurship, focused on the wrong motives, has adopted inadequate and inconsistent definitions of entrepreneurship, has failed to look for indirect effects, and has failed to meta-analyze data across studies. We have offered explicit solutions for future research to adopt to overcome these problems. By providing specific recommendations for how to overcome each of these problems and by offering an example of how motivations might influence the entrepreneurial process at each of its stages, and in concert with cognitions, opportunities, and environmental forces, we hope to advance the rigor and useful results from research on motivation and entrepreneurship. After all, if even sociologists who have argued strongly and repeatedly against the usefulness of trait-based research in entrepreneurship acknowledge that motivated entrepreneurs are important to the entrepreneurial process, then the inclusion of human motivation in our theories of the entrepreneurial process is crucial. 


\section{References}

Aldrich, H. (2000). Organizations evolving. Beverly Hills: Sage.

Aldrich, H., \& Zimmer, C. (1986). Entrepreneurship through social networks. In D. Sexton, \& R. Smilor (Eds.), The art and science of entrepreneurship ( pp. 3-23). Cambridge, MA: Ballinger.

Aldridge Jr., J. H. (1997). An occupational personality profile of the male entrepreneur as assessed by the 16PF fifth edition. Unpublished doctoral dissertation, University of Georgia.

Amit, R., Meuller, E., \& Cockburn, I. (1995). Journal of Business Venturing, 10, 95-106.

Atkinson, J. W. (1957). Motives in fantasy, action, and society. Princeton, NJ: Van Nostrand.

Babb, E. M., \& Babb, S. V. (1992). Psychological traits of rural entrepreneurs. Journal of Socio-Economics, 21, 353-362.

Bandura, A. (1997). Self-efficacy: the exercise of self control. New York: Freeman.

Bates, T. (1990). Entrepreneur human capital inputs and small business longevity. Review of Economics and Statistics, 72(4), 551-559.

Baum, R. (1994). The Relation of Traits, Competencies, Vision, Motivation, and Strategy to Venture Growth. Unpublished doctoral dissertation, University of Maryland, College Park, MD.

Baum, J. R., Locke, E. A., \& Smith, K. G. (2001). A multi-dimensional model of venture growth. Academy of Management Journal, 44(2), 292-303.

Baumol, W. (1968). Entrepreneurship in economic theory. American Economic Review Papers and Proceedings, 64-71.

Begley, T. M. (1995). Using founder status, age of firm, and company growth rate as the basis for distinguishing entrepreneurs form managers of smaller businesses. Journal of Business Venturing, 10, 249-263.

Begley, T. M., \& Boyd, D. P. (1987). A comparison of entrepreneurs and managers of small business firms. Journal of Management, 13, 99-108.

Bowen, D. D., \& Hisrich, R. D. (1986). The female entrepreneur: a career development perspective. Academy of Management Review, 11, 393-407.

Brockhaus, R. H. (1980). Risk taking propensity of entrepreneurs. Academy of Management Journal, 23, 509-520. 
Brockhaus, R. H. (1982). The psychology of the entrepreneur. In C. A. Kent, D. L. Sexton, \& K. H. Vesper (Eds.), Encyclopedia of entrepreneurship ( pp. 39-57). Englewood Cliffs, NJ:

Prentice-Hall.

Budner, S. (1982). Intolerance of ambiguity as a personality variable. Journal of Personality, 30, 29-50.

Busenitz, L., \& Barney, J. (1997). Differences between entrepreneurs and managers in large organizations: biases and heuristics in strategic decision making. Journal of Business Venturing, 12, 9-30.

Carroll, G., \& Mosakowski, E. (1987). The career dynamics of self-employment. Administrative Science Quarterly, 32, 570-589.

Christiansen, C. (1997). The innovators dilemma. Cambridge: Harvard Business School Press.

Collins, C., Locke, E., \& Hanges, P. (2000). The relationship of need for achievement to entrepreneurial behavior: a meta-analysis. Working paper, University of Maryland, College Park, MD.

Cooper, A., Woo, C., \& Dunkleberg, W. (1989). Entrepreneurship and the initial size of firms. Journal of Business Venturing, 3, 97-108.

Corman, J., Perles, B., \& Vancini, P. (1988). Motivational factors influencing high-technology entrepreneurship. Journal of Small Business Management, 26, 36-42.

Durand, D. E. (1975). Effects of achievement motivation and skill training on the entrepreneurial behavior of black businessmen. Organizational Behavior and Human Performance, 14, 76-90.

Evans, D., \& Leighton, L. (1989). Some empirical aspects of entrepreneurship. American Economic Review, 79, 519-535.

Fineman, S. (1977). The achievement motive construct and its measurement: where are we now? British Journal of Psychology, 68, 1-22.

Fry, F. L. (1993). Entrepreneurship: a planning approach. Minneapolis-St. Paul, MN: West Publishing.

Gartner, W. (1985). A conceptual framework for describing the phenomenon of new venture creation. Academy of Management Review, 10(4), 696-706.

Hisrich, R. D. (1985). The woman entrepreneur in the United States and Puerto Rico: a comparative study. Leadership and Organizational Development Journal, 5, 3-8. 
Hornaday, J. A., \& Aboud, J. (1973). Characteristics of successful entrepreneurs. Personnel Psychology, 24, 141-153.

Hull, D. L., Bosley, J. J., Udell, G. G. (1980). Renewing the hunt for heffalump: identifying potential entrepreneurs by personality characteristics. Journal of Small Business, 18, 11-18.

Johnson, B. (1990). Toward a multidimensional model of entrepreneurship: the case of achievement motivation and the entrepreneur. Entrepreneurship Theory and Practice, 14(3), 39-54.

Kirzner, I. (1973). Competition and Entrepreneurship. Chicago, IL, US: University of Chicago Press.

Kirzner, I. (1997). Entrepreneurial discovery and the competitive market process: an Austrian approach. The Journal of Economic Literature, 35, 60-85.

Kogan, N., \& Wallach, M. A. (1964). Risk taking. New York: Holt, Rinehart and Winston.

Liles, P. R. (1974). New business ventures and the entrepreneur. Homewood, IL: Irwin.

Litzinger,W. (1961). The motel entrepreneur and the motel manager. Academy of Management Journal, 8, 268-281.

Locke, E. A. (2000a). Motivation, cognition and action: an analysis of studies of task goals and knowledge. Applied Psychology: An International Review, 49, 408-429.

Locke, E. A. (2000b). The prime movers: traits of the great wealth creators. New York: AMACOM.

Locke, E. A. (in press). Self-set goals and self-efficacy as mediators of incentives and personality. In M. Erez, U. Kleinbeck, \& H. Thierry (Eds.), Work motivation in the context of a globalizing economy. London: Erlbaum.

Locke, E. A., \& Latham, G. P. (1990). A theory of goal setting and performance. Englewood Cliffs, NJ: Prentice-Hall.

Low, M., \& MacMillan, I. (1988). Entrepreneurship: past research and future challenges. Journal of Management, 14, 139-161.

McClelland, D. C. (1961). The achieving society. Princeton, NJ: Van Nostrand.

McClelland, D. C. (1965). Toward a theory of motive acquisition. American Psychologist, 20, 321-333.

Miller, D., \& Drodge, C. (1986). Psychological and traditional determinants of structure. Administrative Science Quarterly, 31, 539-560. 
Palich, L. E., \& Bagby, D. R. (1995). Using cognitive theory to explain entrepreneurial risktaking: challenging conventional wisdom. Journal of Business Venturing, 10, 425-438.

Rotter, J. B. (1966). Generalized expectancies for internal versus external control of reinforcement. Psychological Monographs: General and Applied, 80, 609.

Sarasvathy, D., Simon, H., \& Lave, L. (1998). Perceiving and managing business risks: differences between entrepreneurs and bankers. Journal of Economic Behavior and Organization, 33, 207-225.

Schere, J. (1982). Tolerance of ambiguity as a discriminating variable between entrepreneurs and managers. Academy of Management Best Paper Proceedings, 42, 404408.

Schoonhoven, C., Eisenhardt, K., \& Lyman, K. (1990). Speeding products to market: waiting time to first product introduction in new firms. Administrative Science Quarterly, 35, 177207.

Schumpeter, J. A. (1934). The theory of economic development. Cambridge, MA: Harvard University Press.

Sexton, D.L., \& Bowman, N.B. (1986). Validation of a personality index: comparative psychological characteristics analysis of female entrepreneurs, managers, entrepreneurship students, and business students. Frontiers of entrepreneurship research (pp. 513-528). Wellesley, MA: Babson College.

Shane, S. (2000). Prior knowledge and the discovery of entrepreneurial opportunities. Organization Science, 11(4), 448-469.

Shane, S. (2001). Technology opportunities and new firm creation. Management Science, 47(9), 1173-1181.

Shane, S., \& Venkataraman, S. (2000). The promise of entrepreneurship as a field of research. Academy of Management Review, 25(1), 217-226.

Shapero, A. (1977). The displaced, uncomfortable entrepreneur. Psychology Today, 9, 8388.

Tracy, K., Locke, E., \& Renard, M. (1998). Conscious goal setting versus subconscious motives: longitudinal and concurrent effects on the performance of entrepreneurial firms. Paper presented at the meeting of the Academy of Management, Boston, MA.

Venkataraman, S. (1997). The distinctive domain of entrepreneurship research: an editor's perspective. In J. Katz, \& R. Brockhaus (Eds.), Advances in entrepreneurship, firm emergence, and growth, vol. 3 (pp. 119-138). Greenwich, CT: JAI Press. 


\section{Zahra, S., \& Dess, G. (2001). Entrepreneurship as a field of research: encouraging dialogue and debate. Academy of Management Review, 26(1), 8-11}

\footnotetext{
${ }^{1}$ By this definition, we do not imply that the study of firm formation is unimportant. We believe that firm-founding entrepreneurship is an interesting and important special case of entrepreneurial activity and one that is in need of greater study.

2 Interested readers might note that this definition is consistent with several classical definitions of entrepreneurship, including those of Kirzner (1973) and McClelland (1961) who argue that people other than business owners or founders can be entrepreneurs.

${ }^{3}$ We do not deny that there may be interactions between environmental and motivational variables, nor do we deny that entrepreneurs may take actions that modify the environment. However, we suggest that it is important for researchers to understand the main effects of these variables before they explore more complex interaction effects.

${ }^{4}$ Readers should note that this approach is effective in measuring the exploitation of an entrepreneurial opportunity but not the discovery of opportunity. Entrepreneurs do not need to be in an industry to discover an opportunity in it. However, to exploit an opportunity in a given industry, they must, by definition, be in that industry.

${ }^{5}$ When discussing prior empirical research, we have identified the definition of entrepreneurship used wherever possible.
} 